\title{
The Issue of Genre in Pekić's Early Opus
}

\section{Ljiljana Pticina}

Faculty of Philosophy, University of Novi Sad Language and Literature - Doctoral Studies

\section{Abstract}

The paper presents the analysis of genre definition of Pekić's prose. Genre definition of the prose work The time of miracles is mainly analysed and explained, which theoreticians define differently, determining it as a chain, stories, but also as a novel. The analysis of the corpus, that is, the works The time of miracles and New Jerusalem is conducted through the prism of Bakhtin's theory on the novel, with a brief resistance of Lukacs' theory to Bakhtin's when it comes to the analysis of Pekić's prose. After the explanation of the characterisation of The time of miracles as a novel, we deal with chronotope, as genre definition, where the most common chronotopes that we encounter in Pekić's prose are indicated. The novelties that Pekić brings to Serbian literature are reflected in one complete novelistic image, a parallel world, documented by historical sources, the witness' stories, archeological sites. Generally speaking, the central point of his work is occupied by problematising man's position in the world in general - so, also in the past, present, but in the future as well. And precisely that and such his relation towards culture and existence - erudite, problematising, predictive, revealing - is "analogous to the correlations between chronotope within the work" (Bakhtin, 1989, p. 386).

Keywords: postmodernism, genre, novel, Bakhtin, Pekić

\section{Introduction}

Many theoreticians, such as Aristotle (Poetics), Tomashevsky (The theory of literature), Lukács (The theory of the novel), Bakhtin (On the novel) and Derrida (The Law of Genre) considered genre issues, thus the classification into lyric poetry, epic poetry and drama is well-established. Bearing in mind these three notions, it seems easy to define the genre of an individual work. However, with the advent of the novel, this task became somewhat more complex for literary theorists. It is no longer simple to decide which epithet could, in this context, possibly be attached to the title of a book, especially if it is epic and the novel. We had epics in the past, which Bakhtin sees 
as rigid formations1, in order to slowly create the environment for the formation of the novel and so that we would be standing today in the place where its form is not finished yet, at the place in time where there still is not an established pattern for writing novels. There is no pattern, no mold we could follow to be sure to write something we can call a novel. Notably, postmodernists use the openness of the novel in this aspect for various combinations of alphabet, lines, essays and many other forms. Some theoreticians think that the end of postmodernism is nearing as well, that is, that we are entering the period of post-postmodernism. It appears as postpostmodernism and a criticism of the creed that everything is acceptable in architecture and urban planning in architect Turner, who wrote about it in 1995, and then it appears as trans-postmodernism in Epstein in 1999 in a book on Russian postmodernism. One of our greatest literary theoreticians Alexander Flaker, who also reflected on this issue in an interview for "Politika" (2008), when he voiced his displeasure with the notion postmodernism in general, and emphasised his ars combinatoria, which postmodernism really is 2 . " "

The paper will analyse the statements of literary theoreticians about the opus of Borislav Pekić, more precisely, their views on the genre issue and definition of Pekić's opus. Next, the characteristics of postmodernism in Pekić's works will be analysed and specifically demonstrated in two works - The Time of miracles and New Jerusalem. Although the sotie How to quiet a vampire presents Flaker's ars combinatoria, we decided on The Time of miracles as the novel which some theoreticians believe to be the beginning of postmodernism in Serbian literature. New Jerusalem represents a collection of short stories with the biblical subtext and the criticism of history as a science, and so these two works can serve as research corpus, that is, sample works in which we can find necessary elements for analysis. We will also discuss the acceptance of Pekić's opus in Serbian and world literature. We will rely on the theory of Mikhail Bakhtin for the analysis of the characteristics of the novel.

1 "We talk about an epic as a definite real genre that reached us. We find it as already completely finished, even rigid and almost dead genre. Its perfection, persistence and absolute artistic non-naivete, speak about its long past, about it being as old as the genre. (...) Whatever its origin, the real epic that reached us is absolutely completed and perfect genre form, whose constitutive feature is the transposition of the depicted world to the absolute past of national beginnings and endings " (Bakhtin, 1989, p. 446-447).

2 "It is reduced to that, because it is the period when literature stopped inventing something, a new style, and started to combine old topics. I know that it is the substitute for what the others would call postmodernism. Quoting in general, the whole relation to tradition means taking from the tradition what you need, chewing it over and presenting it in combination with something else" (Politika, 2008, http://www.politika.rs/scc/clanak/63650/\%D0\%9F\%D0\%BE\%D0\%B4\%D0\%B3\%D1\%80\%D0\%B5 \%D1\%98\%D0\%B0\%D0\%BD\%D0\%B8-

\%D0\%BC\%D0\%BE\%D0\%B4\%D0\%B5\%D1\%80\%D0\%BD\%D0\%B8\%D0\%B7\%D0\%B0\%D0\%BC). 


\section{On the novel in Pekić and in general}

Before starting the analysis, a short explanation for choosing precisely Bakhtin's theory of novel will be given. Lukacs' theory of the novel seems too rigid for the age of postmodernism and to a certain degree, it still strives to canonise and mold, while Bakhtin observes the novel as a literary form, which has not become rigid yet, and which carries in itself the change of both genres and literature itself. Indeed, Lukacs states that the novel, as a form, "presents an inconsistent balance" (Lukacs, 1990, p. 58), while claiming that it requires "even more strict and more infallible artistic norm than the norm of 'closed forms " (Lukacs, 1990, p. 58), specifying tact and taste as the laws that the novel has to adhere to. We will allow ourselves the freedom here to remark how Lucas' laws cannot possibly be measurable, objectively analysed, and consequently, there can never be space for the term "norm". Another thing that could be held against Lucas' analysis today is his comparison of the novel with "mature masculinity" (Lukacs, 1990, p. 56) excluding or disregarding the female principle, female author and reader equally from the birth of the novel.

Further, when it comes to the connection, so to say, of the novel or the novelistic world to the past, the present and the future, Lukacs states that the novel demonstrates "the line that defines the problem and which is the only one important, touching everything that precedes that follows only in perspective reflection and referring to the problem" (1990, p. 65). We find that Bakhtin connects the novel more appropriately, to the past particularly, via his theory of multilingualism. When it comes to the analysis of the postmodern novel, this theory clarifies how and why it gained a new form, where it got its malleability and states that the novel is "pure malleability" (Bakhtin, 1989, p. 473), that it is "a genre which eternally searches, eternally explores itself and re-evaluates all its developed forms" (Bakhtin, 1989, p. 473).

New, and yet changed, type of novel that appears in postmodern literature, is characterised by intertextuality, that is, "plagiarism", where well-known topics or motifs are used in a different way, often with irony. And then, it is characterised by openness, so to speak, intentional incompleteness and the introduction of texts of different genres, such as letters, myths, documents and such like. Then there is citation, and scientism and erudition are very typical of Pekić, which also reflects on his works.

Speaking about the development of the novel ever since the ancient times (that is, creating the conditions for its formation), Bakhtin cites one feature which is thought to be typical of the postmodern novel in the contemporary literary thought. However, he claims that the novel "parodies other genres (just as genres), exposes conditionality of their forms and language, displaces some genres, and introduces others in its internal construction, by rethinking and reaccentuating them " (Bakhtin, 1989, p. 437). At that point, he is primarily thinking about occupying the place in genre classification, while in postmodernism, parody and the exposure of the genre 
forms are placed at the very center of each individual work. Besides, he adds that "consistent parodying or travestying the ruling and fashionable types of that genre, which long for stereotyping, run throughout the entire history of the novel" (Bakhtin, 1989 , p. 438). We could conclude that the postmodern novel is becoming contemporary right at the moment when the novel as a genre is prevailing, when it is showing the tendencies to "settle down", to establish its course, and it, as a carrier of changes, does not have any other way of solving problems except to parody itself, to pull itself out of potential stereotyping. Precisely Bakhtin states that the self-criticism of the novel is its incredible characteristic, especially as a genre in the making (Bakhtin, 1989, p. 438).

Pekić's novels engage in specific problems (again, Bakhtin cites this characteristic) from the point of view of a modern man who more often experiences existential crisis, and ponders and envisages a new future, indicated to him by human development. Orwell predicted in his 1984, the control of man's freedom, creativity, opinion and thinking that we are bearing witness to. So, we, the people of the $21^{\text {st }}$ century, are experiencing the predicted future offered to us by Orwell (in his works 1984 and Animal farm), and Ilić (A million years after), and therefore, it is necessary to think about the next stage, the way a man is to design his life further, and the way, if he will at all, prolong his existence. In "Rabies", Pekić predicts the end of the titan; he predicts that man will manage to "trick" the nature, but only for a short while, because even in that titan, of superhuman strength, those constant base desires, which have been following us since the dawn of civilisation known to us, prevail: jealousy, desire and suicidal thirst for power, the lack of empathy towards others (Matthew, blinded by fear and the instinct for self-preservation, leaves his pregnant wife Andrea to the rabies, fighting to survive: "With wide opened eyes from which the spark of reason was vanishing, Andrea Laverick was left in that darkness, and he, he didn't himself know how, opened the door of the passengers cabin and rolled down the metal steps into the wall of rain which awaited him" (Pekić, 2014, p. 428), selfish impulse for selfpreservation and struggle to acquire material possessions in an obvious decay and dying of everything, even your closest ones. Pekić explains how and why the new race is necessary in the twenty-first chapter of Rabies, and how the genetically modified rabies virus developed in the first place, only for the two survivors from the airport, though infected with this rabies virus, which grants them superhuman strength, to fight each other for the survival and the prolongation of the species, at the end of the novel:

"Two rabies are fighting on the roof of Queen's Building. As far as we can see from here, they are the only survivors" (Pekić, 2014, p. 606).

In the collection of short stories New Jerusalem, Pekić places the events in several key historic events of humankind, whereby the last story is placed in still distant year of 2999, where man goes around in circles, tormented by his ignorance, with the speculations about distant civilisations, parodying also our utopian image of Atlantis 
as a supreme civilisation, one of the best that has ever existed, which is supported by little or no evidence. Such modern man comes across the remains of Gulag in 2999, and he imagines it romantically as our contemporary imagines Atlantis.

When we talk about Pekić and the definition of the novel, we need to reflect on the classification stated by Petar Pijanović. He distinguishes five types of Pekić's novels:

1. the novel without novel or: the destruction of the biblical myth

2. towards the novel, or: two antic motifs in a new key

3. an epistolary novel or: the criticism of a dogmatic mind

4. novel-saga, or: the destruction of myth in history and history in no-time

5. anti-utopian novel, or: the apocalyptic gospels of the witness of the future and future past (Pijanović, 1991, p. 23).

Even in such classification, postmodern characteristics such as questioning myths and the historical narrative in general, can be observed. The classification itself is preceded by Pijanović's genre analysis and he points out that Pekić himself did not call his works novels „I actually did not call any of my books a novel“ (Pekić, 1993, p. 63). All of this leads the researcher of his works into a dilemma how to characterise them, and on the other hand, it presents a certain novelty in Serbian literature itself.

When it comes to the characteristics of his works, they inevitably possess the features of postmodernism, which is obvious from the titles of his works. For example, The Time of miracles, The Pilgrimage of Arsenije Njegovan refer to biblical and religious subtext, and citation is rather quickly observed in the works. Next, the very title 1999 can be reminiscent of George Orwell, Atlantis and The Golden fleece on questioning myths and so on.

\section{Pekić's works and postmodernism}

The beginnings of postmodernism are connected to the sixties and seventies of the $20^{\text {th }}$ century and we can find its influence in all types of art. The postmodern novel "openly demonstrates its propensity for illusory tricks of the manipulation of stereotypes and narrative, openness to multiple interpretations in its entire contradictoriness and inconsistency"(Batler, 2012, p. 89), and there is the "desire to demonstrate its formal organisation to the reader" (Batler, 2012, p. 89).

When it comes to Serbian literary criticism, the beginning of postmodernism is related to three names - Kiš, Pavić and Pekić. The authors disagree to some degree when it comes to the very beginning of Pekić's opus. Namely, while Radovan Vučković considers the first Pekić's novel The Time of Miracles to represent just the initial spark, beginning or indication of postmodernism, Alexander Jerkov already considers this novel to be a postmodern work. However, Vučković places Pekić's early works into Neo-avantgarde, thinking that only the novel How to quiet a vampire presents a different achievement, in which "he (puts) stylistic and technical features of the neo- 
avantgarde novel into the function of a new approach to novel material and the erudite style based on embedding documents into the novel, with a great number of citations from all scientific, literary and historical domains" (Vučković, 2013, p. 601). In his analysis From modernism to postmodernism, Jerkov already refers to Pekić's The Time of miracles as an indication of postmodernism in Serbian literature, also concluding that the turning point in the development, movement of literature is precisely the year 1965, that is, the year in which "three significant novels of a new generation of writers; Garden, Ashes by Danilo Kiš, The Time of miracles by Borislav Pekić and My sister Elida by Mirko Kovač" (Jerkov, 1991, p. 100) were published.

We also encounter different views of genre definition of this work. Pekić himself, as has already been mentioned, does not consider this work, or any other work except The Golden fleece to be a novel, but he calls it a chronicle. Perhaps the reason for such definition is Pekićs intention for The Time of miracles to include two additional chapters - The Time of words and The time of resurrection, besides the two chapters of the novel in the form known to us. A. Tatarenko states that New Jerusalem is a chronicle which becomes a chronicle of "the supposed life of historically unprovable hero - a sort of hagiography, in which a miracle is missing" (2008, p. 124), and after that says that the author "is creating a new historical reality - the reality of his work which defies both History and Legend"(2008, p. 124). In relation to The Time of miracles, the difference is that there is not a lack of miracles in the story of Jesus and Judas, and history and legend are equally balanced. In his thesis Poetics of Borislav Pekić's novels, Petar Pijanović cites this work as the novel without a novel. Referring to Tomashevsky, he states that The Time of miracles includes short stories, the stories the existence of which can be separated from the unity of the work, that is, the unity presented by the work can be destroyed. Indeed, the stories could be read separately, but the ambiguity would remain and the reader's wondering about what came before, and what came after.

In the segment From the Prehistory of Novelistic Discourse, Bakhtin states that the language we encounter in the novel "does not only represent but is itself the object of representing. Novelistic word is always self-critical"(1989, p. 400). As an old genre, it uses already old, established language, but it gives a new sense to that language, a new sense in its unity. From this perspective, we can say that we have another argument why we would characterise The Time of miracles as a novel instead a collection of short stories. Certainly, the short stories could be read individually and the reader with literary background, could only then (whether we want to admit it or not) to a certain degree understand the message Pekic is sending. Only in the presence of other short stories as well does the allusion to biblical discourse become quite clear. Bakhtin cites the example of Don Quixote, which contains sonnet forms, where these sonnets does not present a complete form, but the sonnet is "the object of representing; here the sonnet is the hero of parody" (Bakhtin, 1989, p. 402). Therefore, a short story is not here a mere narrative form, but the object of representing. 
Bakhtin further cites the example of "comic Odysseus" that is actually "a parodic travesty of his supreme epic-tragic figure" (1989, p. 404). Such character is mentioned within the satirical dramas, which Bakhtin says to have been equally canonised and laws as well as the texts which are parodied. Is Pekić digressing here? His Jesus, who we can in no way say to be comic, certainly has different characteristics than those presented in The Bible, however, it is not only he that is parodied, but also other characters, and situations, which will be discussed later. The character of Jesus is parodied by avoiding comic features and buffoonery. In Christianity, that is, The Bible, he is the personification of universal love, understanding, forgiveness, he is the healer, savior of souls, a devoted character who proudly and bravely advances, heading towards death without fear, without hesitation. Jesus in The Time of miracles is a stark contrast. He brings misery through his miracles. Egla, who renounces her obedience to God, is anyway cured of leprosy, but understands very quickly that the cure is a curse because the healthy think that she is unclean on the inside, and the lepers, based on the obvious outer appearance, do not accept her. Egla devastatingly realises that "the unclean and the clean (...) always use the same stones" (Pekić, 2012, p. 90). Next, he is more a puppet of Juda's desire and endeavours to realise the Scripture than he is interested in performing the miracles himself: "Am I not He who is, and Jesus just what I wanted him to be?" (Pekić, 2012, p. 324) Lazarus calls him a "bastard" (Pekić, 2012, p. 250) because Jesus keeps resurrecting him, and Lazarus dies several times, not having found peace.

It is not parodying for the sake of entertainment, but for the purpose of destroying the myth, questioning history, overall belief of a civilisation, not Serbia, not Orthodoxy, not any individual faith. Pekić acts as a true erudite, a true global citizen, providing his novelistic world with a universal character.

The plot itself is biblically charged, and can be observed as an inverted image of Jesus' life, the task in general which is closely related to the saving of the world and humankind in general, the topic which Pekić later deals with from other aspects as well (1999, Rabies). Namely, Jesus does perform miracles, makes people physically recover, the blind see again, the lepers recover, but all those acts, instead of making people happy, elevating them, giving them a positive change in life, make them angry, furious because their life, and so their habits, have radically changed, without their consent. For example, it shows the cripples earning money effortlessly by begging, while lying, counting on people's sympathy. After a miraculous recovery, they are forced to work, which all leads to enormous discontent, escalating in betraying Jesus to the authorities. The Nazarene is not interested in his miracles, nor in fulfilling the Holy Scripture, he is unprepared and would rather avoid that duty. Opposite him, Judas Iscariot is standing, who is a symbol of betrayal in the Christian world, but here acquires a completely different role. He insists that every letter of the Holy Scripture be fulfilled, fearing that the world and the humankind will not be saved, nor their sins redeemed if even the smallest part is changed, missed. Taking Jesus' mission on himself, but not without Jesus, because only he can really perform miracles, he thinks 
of himself as a would-be God, son of God. With a heavy heart, he performs even the last letter which concerns his destiny - he hangs himself from a tree, calm and peaceful that Jesus is taken to Golgotha, where he will sacrifice his life for the universal sin of the humankind, never finding out that Jesus managed to avoid his part of the Scripture by surviving and leaving the humankind without a chance of ever being saved from the sin.

What did Pekić want to achieve by this unexpected turn and generally presenting a mirror image of the Bible? As professor Vladušić states in one of his oral presentations on Pekić, evil inevitably exists, it is especially clear to a modern man, the man following the First and Second World War, which left him painfully wondering how to confront it and what to do, and where it originates at all. Christianty provides the answer that God is omnipresent, that He is love. But, why is there hatred and that evil in His world? Pekić here offers the rethinking of history, legend, destroying the myth which has deceived the humankind for centuries. What if Jesus is not what we imagine him to be and how he is represented? What if the world is not originally redeemed from sin? Instead of salvation, man continues to fight with and against the evil which inevitably exists in the world it happened to be in.

We will now reflect on the gothic chronicle (Pekić's term) New Jerusalem in more details. This work consists of five separate stories, which are connected by the idea of the incompleteness of history as a science, then the topic of death, five elements, each of which is assigned to a single story, and the idea of New Jerusalem, which is summarised in the last story, and which roughly represents the death of man's whole history, the death of a civilisation, the oblivion of everything that existed before the contemporary man of the year of 2999, and the evident failure in interpreting the past in a way characteristic of man. New Jerusalem outlines non-analyticity and noncriticality of a contemporary man which threatens to continue further, condemning thus a man to constantly go round in circles, in search of his past, his identity.

Two motifs figure in each story, and those are the motif of the flute and the motif of the spindle. They indirectly lead to the fundamental, main motif - the motive of man's death (perhaps even the death of history, but not narration) and thus hold the thread that links these five stories. According to the DoS1, the sound of the flute is "heavenly music, the voice of an angel"(DoS, p. 222), while the spindle refers to eternal return. "The spindle spins with uniform movements and leads to the revolving of the cosmic whole" (DoS, p. 1068), it represents "a type of automatism in a planetary system"(DoS, p. 1068), and simultaneously links three time dimensions: the past, present and future, indicating the inevitability of fate. In the story, the spindle first appears in defense of the spinner Germaine, whose judgement was the first Popier ate. The same night, after that, he dreams of the iron spindle which is the symbol of guillotine, because he does not know what guillotine actually looks like. Iron is cold, dead,

1 Dictionary of Symbols, DoS is going to be used in the text. 
belongs to the chthonic world, and in combination with the spindle, it certainly implies death. In the same dream, there is the flute: "From somewhere, instead of the drums, which accompanied all the executions with their rumbling noise, I heard soft, melodious sound of the flute. The tune was cheerful, and even daring, little suited the scene"(Pekić, 2014: 113), and we also encounter it at the very end of the story, at the moment they are taking him to the guillotine to execute him.

Could we call these stories novellas? We could certainly draw a parallel with Meyer. Meletinsky writes that he is "a poet of unresolved contradictions, and not on a social (as in Keller), but on a metaphysical level: between a man and society, life and death (...) " (1996, p. 296), then in Pekić: between man and history, between narration and history, between inner turmoils of the hero and the world around him. "Contradictions, as a rule, are insoluble, and the best escape for most of his heroes is death" (Meletinsky, 1996, p. 296), and we have a similar situation in Pekić: the craftsman from the first story died of plague after he had finished his life's work, but he did not deliver it to the patron, but kept it for himself, while he sent out a copy; in the second story, the death of others is the salvation for the accuser of witches; in the third, a man ends up on a guillotine after he woke his inner, till then unknown (to himself as well) mechanism for evaluating whose life is worth saving, divinity in him would grow until he was equal with his enemy, and death saved him from the depth of hunger and the thirst for power; in the fourth, one of the actors of the story commits surreal suicide, fighting his own demons of conscience, and the fifth - the fifth is a death of a civilisation, its historical meaninglessness and the elevation of the residents of Gulag to the perfect and incomparable, just civilisation. When it comes to characters, they are not described in detail, which often makes a character itself elusive, and if we want to describe it, we will not succeed, only the outline is given. However, on the basis of actions, inner dialogues, the outlines of characters indeed, gain a full form. The action is initiated out of their characters. For example, in the story, The imprint of a heart on the wall, Blacksmith begins his story with a description of accidental identification of a witch from the neighborhood, so the reader is thinking that the gift is simply given to the child or that the child's imagination or fear directed his finger towards the neighbor's window. Further in the story, he seems righteous, sometimes vain, but humble. "Duty, if it existed, was, towards my gift, divine, so, not mine, human" (Pekić, 2014, p. 85) Only close to the end do we find out where all the courage, resolve, commitment to witch hunt come from. It is somewhere first implied: "Drawing blood would do little good. I was supposed to die. And nobody knew that" (Pekić, 2014, p. 88), and only at the very end of the confession do we discover the true nature of the boy's clairvoyance. He identified those equal to him. "And so far I have flown without any fuel. Just on a broom“ (Pekić, 2014, p. 94).

\section{Chronotope as a genre definition}

Bakhtin thinks that in order to define genre features, time and space are of crucial importance, that is, what he calls by one name, chronotope. "The features of time are 
revealed in space, and space is created and measured by time. Artistic chronotope is characterised by that intersecting of sequences and fusing features" (Bakhtin, 1989, p. 194).

How does Pekić build his novelistic world? To him, it is important to place the plot at a certain historical point, and so we often find years in his works, which specify when the narration takes place. For example, every story in New Jerusalem is linked to a precisely determined year, hence the title of the novel 1999. If there is not a year, there is a certain time period which thickens to the biggest possible boundaries, as well as the place of the event (a ditch in Miracle in Jabneel, the apartment of Arsenije Njegovan, the airport in Rabies, the cramped workspace of Popier). A man is squeezed into a corner, a micro-image of society is given and in general, a psychological idea of different characters. Although pushed like that, the actors are sent on the road, which further moves the plot. It is not usually a long road, but getting out of one's safe space - Arsenije Njegovan leaves his apartment only to encounter unpleasant events again, which originally trapped him in the apartment, then Popier leaves his workspace to see a guillotine, where he later dies, Jesus the Nazarene goes from place to place so that the Holy Scripture starts happening, that is, realising.

One of evident features of Pekićs narration is death, and with regard to that, accentuated physicality, that is, materiality. We often come across descriptions of torture, then inner fight that is manifested in physical characteristics, as with Popier (New Jerusalem, The man who ate death). "He had a small, thin body that did not release water. It did not release it, although, at times, it seemed to him that he is made of it. That, except water, he does not have anything else within himself" (Pekić, 2011, p. 111). He originally retains water in himself, he does not sweat with fear nor pressure, only to start sweating profusely and urinate occasionally after the first paper meal, which leads him to the act of mercy, that is, concealing judgement. Later, simultaneously with the intensified counter-revolutionary activism, the water which shoots out of his body also intensifies. "He is sweating, alas, more than if he were wearing a coat in the heat. He keeps going to the toilet. He felt the water in himself before, but he never thought there was so much of it" (Pekić, 2011, p. 115). Souls need water to live, and in Popier it stagnates, there is no movement, it keeps him alive. At the moment it leaves his body (again the chronotope of the road, but the road of water through the body), and which matches his actions of saving people from the guillotine, it can quite clearly represent the soul cleansing, by purifying, expelling dirty, unclean waters from the organism. Namely, the only water mentioned is his sweat and urine, which is considered unclean.

In The Time of miracles, physical defects, diseases are depicted. In the story about Egla, the torture that she endures willingly is described in detail, because it is the torture of soul, the struggle between love towards two men, the leper and non-leper, hatred towards any god and her punishment she believes to be undeserved. Rolling down the border between two cities, two worlds, the clean and the unclean, she suffers for 
the love she left behind and which she listens to every night. "(...) started scraping her limbs on the rock, scratching her face with her nails and whimpering like a young animal in its death throes, swallowing sand moist with tears, mucus, sweat and urine.(...)" (Pekić, 2012, p. 49). Here also, we encounter unclean bodily fluids, which can be a sign of Egla's spiritual preparation for the healing that Jesus brings her. Everything is materialised here, in order to emphasise the distance from spirituality, from God. Pekić writes the noun god with the initial letter in lower case as a narrator, and when one of the actors mentions it, one of the "faithful" and believers, in capital initial letter, whereby the distance of the author from the dogmatic traps is additionally emphasised. By emphasising the individuals, physicality, Pekić demonstrates what kind of strength and influence, the ideology has on a man. A man in ideology, dogma is a marginal factor, replacable, his pain, his fate, his identity, freedom - everything disappears, and is subordinate to the greater good, in the name of God, in the name of Church, and in the name of the Holy Scripture or anything else:

"Because, what chance of success does the potential wish of a patient not to get better have if the act of healing has a higher purpose than health itself, if, at first instance, it illustrates a supernatural benefit, and only incidentally provides natural benefit to a chance beneficiary?" (Pekić, 2012, p. 145)

In what manner does Pekić introduce a reader to the world of The Time of miracles? The signs which give the impression of the time of distant history are the quotations from The Bible, then sentence constructions, aorist, and the dictionary we can find within it, which is especially evident in The Annunciation and Miracle at Cana, which also present the introduction to further events, but also introduce the main actors Jesus the Nazarene and Judas Iscariot: And there was evening and there was morning./they said/ you cry out after me/ it already seemed as if he did not see it.

New Jerusalem opens with a quotation from the Book of Revelation, suggesting thus the orientation towards the future, towards the vision of a new, in humankind's hopes, better world. Pekić's vision, as well as in The Time of miracles, the fate of humankind is not anywhere close to the one preached by the official religion. We find the interconnection of the five stories of this gothic chronicle, their common mission not only in the initial quotation, which perhaps tells it in a more metaphorical manner, but also in the first story about Megalos Mastoras: "as if the entire past is to be encompassed by the same narrative breath or the forced unification of independent images is the act of the past itself, when it comes back, when it speaks about itself" (Pekić, 2014, p. 11). Wondering why Pekić describes precisely these, seemingly insignificant events from the past, we have to bear in mind what he implies by history and narration. There is certain synonymy which is used when it comes to the terms history and storytelling, with the latter often considered a croatism. What do these two terms signify in Pekić? In short, it could be said that storytelling is a history story, and history is the story of a bloodhound, that is, historiographer, just like the one in New Jerusalem. History belongs to the ruling classes and their interests, narration 
belongs to people. "Big dates of history tend to block insignificant dates, although the lives of the people, and sometimes that history as well, may depend on them, those insignificant events" (Pekić, 2014, p. 14). Such Pekić's vision of the future does not promise, it forces to reconsider both the world, and man, starting with one's inner being. The first three stories are told by the narrator, referring to various sources such as legends, lost, old manuscripts, while in the last two stories, the narrator is also a hero of the narration. In the first three, Pekić salvages the sources from the past and oblivion, placing in front of the reader a man, a representative of a certain time, which is much more than withered notes of history books. In the fourth, two main actors belong to the present, they are living witnesses to the past, which warns them by the flute music and the appearance of the spindle. The author's friend is haunted by the "golden" high school days, when he did not show solidarity with his friends. Besides, this story is a middle, a border, a connection between the past and present, before Pekić reflects on the past from the future perspective: "In that wondrous moment of spiritual entropy, in which, on the other side of the window, our only barrier, history was taking place, the two of us, two grown children, were sitting petrified, dead, killed before it could occur to anyone at all that we were living" (Pekić, 2014, p. 174). The main feature of the The fire of New Jerusalem is an unknown, a great distance in time in relation to the archeological site and the discoverer, where Pekić outlines the way in which also a man of today reveals history, with the help of speculations, associations originating from the sources and his meager knowledge, creating great misconceptions.

Chronotope is the materialization of time. What happens when two historically distant times cross? Pekić approaches biblical time, mythical events from the position of a contemporary man, equipped with knowledge, but also with a possibility to observe differently, more objectively the events which happened or are believed to have happened. He parodies bible stories in order to demythologise one of the oldest dogmas and figures to indicate the possibility that a contemporary man has a mistaken perception of history, that he is blinded by dogmas not allowing himself one bit of doubt about what was written a long time ago, which happened a long time ago. Pekić reduces myth to everyday life ("And there was Joshua ben Joseph, Jesus the Nazarene, Savior of the world. Who knows which day, every day" (Pekić, 2012, p. 14)), and thus humanises, exposes exalted personalities, historically distant to us, for example, by saying the following words to Nathaniel about Jesus and the apostles: "if we had nothing better to do than yawn and prepare ourselves for the heavenly kingdom by exercising our jaws" (Pekić, 2012, p. 24). Pekić represents them as a group of idle, poor men who are waiting for the Scripture to happen, and in that waiting, they do not give the impression of contrite, spiritual individuals, but people with sins and doubts. Each story takes place in a different place, whereby it is named, which actually establishes the chronotope of the road, which enables intersecting, Bakhtin emphasises "at one time and space point of space and time path of different people, representatives of all classes, conditions, nationalities, ages“ (Bahtin, 1989, p. 
373). Each movement leads to the culmination of the novel (one more reason for the opinion that this work is nevertheless a novel), that is, a glorious misunderstanding between the heaven and earth, as Pekić states at the end (Pekić, 2012, p. 402). By reflecting on the very beginning of the novel, where the author cites a somewhat changed quotation from the Ecclesiastes, that is, The Old Testament, it becomes clear that a man returns to himself, and that he is on his own because "what has been will be again, what has been done will be done again; there is nothing new under the sun".

When it comes to New Jerusalem, we could say that we have a sort of the chronotope of meeting. Every actor in five stories has a profound, spiritual meeting with himself, where he can analyse himself in the past and himself at the moment he is in and that provides him with the possibility of self-knowledge unattained up till then, looking into the sheer network of one's own thoughts, feelings, intentions and readiness to act, and which is most clearly emphasized in the story The Fiddler from the Golden Time, because the motive of a double is introduced. It is a mirror in which a man directly meets the past and after confronting himself, he disappears: "Nothing pointed to him being dead, or alive. He disappeared just as perfectly as a hunted indian warrior disappears(...)“ (Pekić, 2014, p. 176).

Likewise, for example, Kir Angelos realises how much art is important for his life, in which he is helped by the appearance of the Stygian man, the customer he was supposed to make the best chair in the world. "It was not about the stranger's conscience, but his own. (...) Art was above them both. And needs, and rights. Above all“ (Pekić, 2014, p. 46).

What pervades the works analysed here is one important element, each time covered in different disguise, and that is death. Death is uncertain in The Time of miracles, death is the sacred bringer of change, through his death Judas paves the way for the realisation of the Scripture, Christ prevents that same Scripture by avoiding his death and changes the whole destiny of humankind. On the road to the realisation of the Scripture, death is lurking: Lazarus, who has to die in order to be resurrected, but that dying is turned into a parody in order to emphasise the blindness by faith and ideology, then physical withering of prostitutes, which are spiritually untouched, identical, but physically transformed into virgins. In New Jerusalem death is, as has already been mentioned, the way out of the situation in which heroes are placed, but not just any way out. Deadly previous spiritual transformation or spiritual selfawareness, pointing the finger at the little man, who nevertheless, no matter how worthless he seems to history is important for its course. Next, in The fire of New Jerusalem we have the death of history and its rebirth, the death of civilisation and the birth of interpreter, bloodhound. Death is the only thing that is certain and sure.

\section{Conclusion}

The novelties that Pekić brings to Serbian literature primarily reflect in one complete novelistic image, one almost parallel world, which is entirely his creation, 
documented by historical sources, the witnesses' stories, archeological sites. Pekić, like an objective observer, walks through history, from the Old Testament to the future, the year of 2999, when a man from the future believes to have discovered New Jerusalem, which is a perfectly created allusion to all the mistakes men make in dealing with history. That world represents harsh criticism for the man of today about quite open acceptance of everything given to him on a historical plate, unwilling to investigate, ask, analyse, staying in one's own safe haven, forgetting that death is inevitable and that in it, we are all equal.

In this analysis, the largest part is dedicated to The Time of miracles as a work which is not often defined as a novel, but, for example, a chain 1 or a collection of short stories, which we have already rebutted through numerous examples. A novel of gradational course, moves from the summarised Old Testament to Jesus' high treason of mankind, and Jesus himself, even if he does not figure in each story individually as a central figure, constitutes their unavoidable foundation, making those stories closely connected through sense. It could be said that the miracles play the main role, just as in the novel Rabies that function is assumed by the illness itself.

Generally speaking, the central point of his work is occupied by problematising man's position in the world in general - so, also in the past, present, but in the future as well. And prescisely that and such his relation towards culture and existence - erudite, problematising, predictive, revealing, destructive towards myths and dogmas, inquisitive - is "analogous to the correlations between chronotope within the work" (Bakhtin, 1989, p. 386).

\section{References}

[1] Bahtin, M. (1989). O romanu. Beograd: Nolit.

[2] Batler, K. (2012). Postmodernizam - sasvim kratak uvod. Beograd: Službeni glasnik.

[3] Flaker, A. (2008, November, 18). Podgrejani modernizam. Politika. http://www.politika.rs/scc/clanak/63650/\%D0\%9F\%D0\%BE\%D0\%B4\%D 0\%B3\%D1\%80\%D0\%B5\%D1\%98\%D0\%B0\%D0\%BD\%D0\%B8\%D0\%BC\%D0\%BE\%D0\%B4\%D0\%B5\%D1\%80\%D0\%BD\%D0\%B8\%D0\%B 7\%D0\%B0\%D0\%BC

[4] Jerkov, A. (1991). Od modernizma do postmoderne. Priština/Gornji Milanovac: Jedinstvo/Dečje novine.

[5] Lukacs, G. (1990). Teorija romana. Sarajevo: Svjetlost.

[6] Meletinski, J. (1996). Istorijska poetika novele. Novi Sad: Matica srpska.

[7] Pekić, B. (ur. Božo Koprivica) (1993). Vreme reči. Beograd: Beogradski izdavačko-grafički zavod, Srpska književna zadruga.

[8] Pekić, B. (2011). Novi Jerusalim. Beograd: Laguna.

[9] Pekić, B. (2012). Vreme čuda. Beograd: Laguna. 
[10] Pekić, B. (2014). Besnilo. Beograd: Laguna.

[11] Pijanović, P. (1991). Poetika romana Borislava Pekića. Beograd: Prosveta.

[12] Pijanović, P., Nešić, B. (ed.) (2017). Deset vekova srpske književnosti. Novi Sad: Izdavački centar Matice srpske.

[13] Ševalije, Ž.\& Gerbran, A., (Eds.). (Et al.). (2013). Rečnik simbola. Novi Sad, Beograd: Kiša, Stylos.

[14] Tatarenko, A. (2008). U začaranom trouglu: Crnjanski - Kiš - Pekić. Zaječar: Matična biblioteka „Svetozar Marković".

[15] Vučković, R. (). Moderni roman dvadesetog veka. Beograd: Službeni glasnik. 